\title{
Effects of social media exposure on adolescent sexual attitudes and behavior: A systematic review
}

\author{
Fransiska Imavike Fevriasanty ${ }^{1}$, Bagong Suyanto ${ }^{2}$, Oedojo Soedirham ${ }^{3}$, Rahma Sugihartati ${ }^{4}$, Ahsan \\ Ahsan ${ }^{5}$ \\ ${ }^{1}$ Doctoral Program of Public Health, Faculty of Public Health, Universitas Airlangga, Surabaya, Indonesia \\ ${ }^{2,4}$ Faculty of Social Sciences and Political Sciences. Universitas Airlangga, Surabaya, Indonesia \\ ${ }^{3}$ Faculty of Public Health, Universitas Airlangga, Surabaya, Indonesia \\ ${ }^{1,5}$ Nursing Science Program, Faculty of Medicine, University of Brawijaya, Malang, Indonesia
}

\begin{abstract}
Article Info
Article history:

Received Jan 8, 2021

Revised Mar 2, 2021

Accepted Mar 11, 2021

\section{Keywords:}

Adolescence

Sexual attitudes and behaviors

Social media exposure

ABSTRACT

Aside from the role of family and peer groups, social media is also one of the major agents of sexual socialization in adolescents. Since it is relatively easy to connect to the internet these days, these people now have a wider access to pornographic content that could trigger them to engage in risky sexual behaviors. This review aimed to provide an analysis of the influence of social media exposure on adolescent's sexual attitudes and behavior as well as describe limitations of the studies being reviewed. This study was based on several electronic databases namely Google Scholar, Science Direct, Proquest Health and Medical Complete, Proquest Science and Pscycholgy Journals, and PubMed, from 2011 to 2018, which revealed a total of 1351 research articles, with only 21 articles meeting the inclusion criteria and reviews. The result showed higher percentage of studies under reviewed mention the effect of social media exposure are related to sexual attitudes, behaviors, initiation and risks, as well as parental monitoring, academic achievement and gender. Conclusively, it is recommended to educate adolescents about the negative risks of social media exposure on sexual attitudes and behavior, as well as the importance of the role of parental monitoring of restrictions on sexualized media access.
\end{abstract}

This is an open access article under the CC BY-SA license.

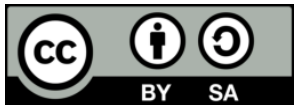

\section{Corresponding Author:}

Fransiska Imavike Fevriasanty

Nursing Science Program, Faculty of Medicine

University of Brawijaya

Veteran Street, Malang, East Java, Indonesia

Email: fransiska.imavike.fevriasanty-2017@fkm.unair.ac.id; imavike@gmail.com

\section{INTRODUCTION}

Adolescence is a stage of human development that causes significant changes in the physical and psychological wellbeing of every male or female individual in society. Risky behaviors such us smoking, substance abuse, alcohol use and illicit sexual interactions carried out by adolescents may have a life-long effect on their entire health and social status [1]-[5]. Since there is a rapid increase in the number of internet users, there is a possibility that these adolescents might engage in online events that could increase the likelihood of them involving themselves in sexual relations with the opposite sex [6]-[9].

However, media and internet access allow adolescents to obtain information about their sexuality and that of the people around them. In addition, the internet can also be used by them to find out various informational content about a wide range of topics and subjects that they may or may not be interested in. They open internet sites that offer pornography because they are driven by their curiosity to know certain 
things about the sexuality of the opposite sex, or because of coincidental factors that may cause them to open these sites [10]-[12]. The male adolescents have been known to open more pornography sites as compared to their female counterparts [13],[14]. Furthermore, websites containing these kind of content attracts their attention because the majority of the media offer videos and images that increases their interest and need to try out what they have seen in the real world [15]-[17].

They also make use of television to get information about sexual behaviors, which may cause them to take part in various sexual activities [18], [19]. Moreover, adolescents also use online communication to explore their sexual desires, where the habits of these individuals can have a negative impact on their sexual activities and health such as unprotected sex with casual partner [20], [21]. Hence, the role of parents becomes very important when trying to limit adolescents' access to the internet or television media [22], [23]. This paper is required to review journals related to the influence of social media exposure on the sexual attitudes and behavior of adolescents since the increase usage of social media as a means of teen sexualization nowadays. Moreover, it also aims to provide useful suggestions for future studies, since this paper explore more previous studies' limitation.

\section{RESEARCH METHOD}

\subsection{Search strategy}

Several electronic databases were searched for relevant publications, including; Google Scholar, Science Direct, Proquest Health and Medical Complete, Proquest Science and Pscycholgy Journals, and PubMed, from 2010 - 2018. Various combination of keywords were used in the database search, namely "media," "pornography," "sexual content," "social media," "sexual explicit material," "adolescence," "teenage," "youth," "young adult," "quantitative study."

\subsection{Selection criteria}

The inclusion criterias used were (i) The research article is a complete text and has passed through peer-reviewed processes, (ii) The research population are adolescents or young adults, (iii) Topics were based on research on the effect of social media exposure on adolescent sexual attitudes and behaviors, (iv) Quantitative studies. The articles that were excluded from the selection were review articles.

\subsection{Data extraction}

The studies obtained from several electronic databases revealed 1351 research articles. After removing duplicates, 985 articles were retained and were also reviewed based on the fulltext of the article. Finally, 21 articles met the inclusion criterias and they were reviewed according to the author, year of publication, study design, population, sample size, kind of media exposure, the effects as well as study outcomes. The preferred reporting items for systematic reviews methodology (PRISMA) was applied, and below is the PRISMA flow chart of this current study as shown in Figure 1 [24].

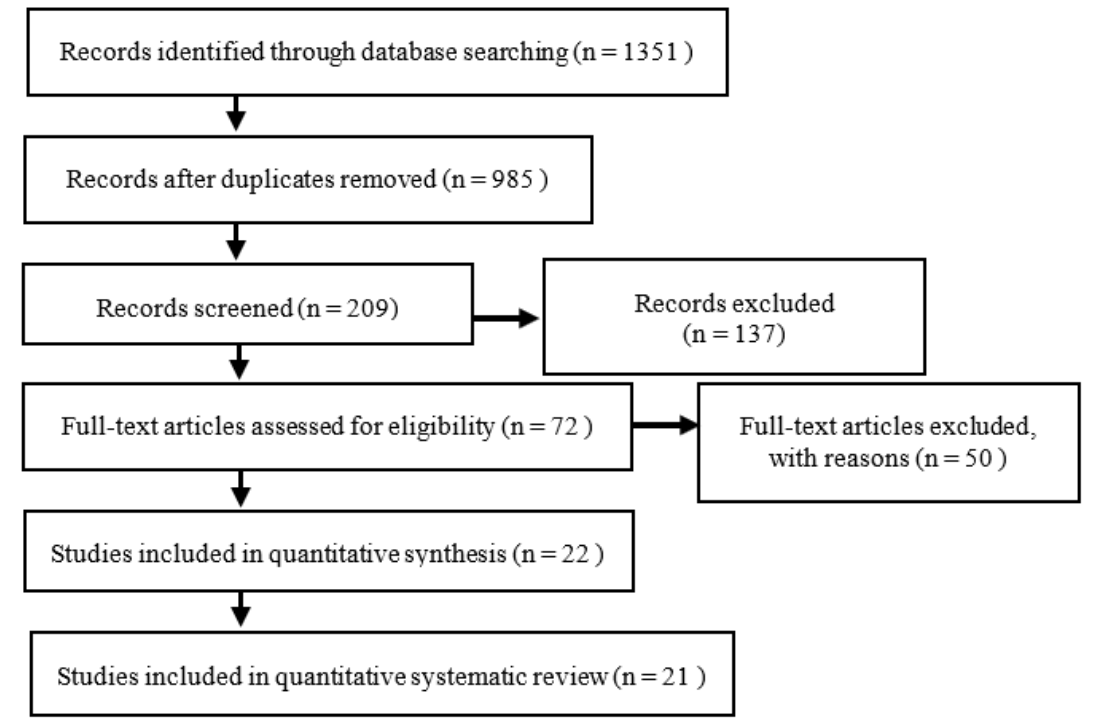

Figure 1. PRISMA Flow diagram: Identified studies reviewing the effect of social media exposure on the adolescent's sexual attitudes and behavior 


\section{RESULTS AND DISCUSSION}

The 21 articles reviewed which met the inclusion criteria were published in 2011 with the most recent paper being published in 2018. From the studies analysed, three research projects were conducted in Sweden, five were carried out in Belgium, four were done at Dutch and the other papers were carried out in China, India, Europe, United States, Croatia, Spain and Hispanic. Furthermore, nine projects had a crosssectional design, two had a two-wave design, three projects had a three-wave design, one study had a fourwave design, and the other projects used survey methods for both online and room-based classes. In terms of the type of pornographic media used by adolescents, seven projects used sexual explicit media (SEM), four projects used television, three projects used sexual explicit web, three projects used social networking sites (Facebook profiles), two projects used sexting and one project made use of magazines. Other reviewed studies are summarized in Table 1.

Table 1. Details of the individual projects in this review

\begin{tabular}{|c|c|c|c|c|c|c|}
\hline $\begin{array}{l}\text { Author (s)/ } \\
\text { year }\end{array}$ & Study design & $\begin{array}{c}\text { Study } \\
\text { population }\end{array}$ & Sample size & $\begin{array}{l}\text { Type of social } \\
\text { media exposure }\end{array}$ & $\begin{array}{l}\text { Effect of social } \\
\text { media exposure }\end{array}$ & Study outcomes \\
\hline $\begin{array}{l}\text { Svedin, } \\
\text { Akerman and } \\
\text { Priebe/ } 2011\end{array}$ & $\begin{array}{l}\text { Cross } \\
\text { sectional }\end{array}$ & $\begin{array}{l}\text { Swedish } \\
\text { 3rd year } \\
\text { high school } \\
\text { students } \\
\text { (males) }\end{array}$ & $\begin{array}{l}\text { Frequent } \\
\text { users } \\
\text { group=200 } \\
\text { Reference } \\
\text { group=1661 }\end{array}$ & $\begin{array}{l}\text { Internet } \\
\text { Cable- or } \\
\text { satellite-TV }\end{array}$ & $\begin{array}{l}\text { Sexual attitudes } \\
\text { and behavior } \\
\text { Sexual initiation }\end{array}$ & $\begin{array}{l}\text { Pornography has inspired } \\
\text { teenagers to try what they } \\
\text { have seen }(\mathrm{p}<0.001) . \\
\text { Regular users registered } \\
\text { sexual debut more } \\
\text { frequently before their age } \\
15 \text { years old }(\mathrm{p}<0.001)\end{array}$ \\
\hline $\begin{array}{l}\text { Vandenbosch } \\
\text { and } \\
\text { Eggermont/ } \\
2012 \mathrm{a}\end{array}$ & $\begin{array}{l}\text { Two-wave } \\
\text { panel study }\end{array}$ & $\begin{array}{l}\text { Belgium } \\
\text { adolescents } \\
\text { age } 12-16 \\
\text { years old }\end{array}$ & $\begin{array}{l}639 \\
\text { students } \\
(373 \text { boys } \\
\text { and } 266 \\
\text { girls) }\end{array}$ & $\begin{array}{l}\text { Sexually explicit } \\
\text { websites }\end{array}$ & Sexual initiation & $\begin{array}{l}\text { Adolescents in the early } \\
\text { pubertal stage }(6 \%) \text { were } \\
\text { less likely than } \\
\text { adolescents in the } \\
\text { advanced pubertal stage to } \\
\text { have initiated sexual } \\
\text { intercourse }(13.7 \%) \\
(\mathrm{p}<0.001) .\end{array}$ \\
\hline $\begin{array}{l}\text { Vandenbosch } \\
\text { and } \\
\text { Eggermont/ } \\
2012 \mathrm{~b}\end{array}$ & $\begin{array}{l}\text { A quantitative } \\
\text { survey }\end{array}$ & $\begin{array}{l}\text { Belgium } \\
\text { adolescents }\end{array}$ & $\begin{array}{l}1,026 \\
\text { respondents } \\
\text { (boys mean } \\
\text { age }=16.41, \\
\text { girls mean } \\
\text { age }=16.23 \text { ) }\end{array}$ & Television & $\begin{array}{l}\text { Sexual } \\
\text { socialization } \\
\text { Gender }\end{array}$ & $\begin{array}{l}\text { The higher the level of } \\
\text { television viewing, the } \\
\text { more boys adopted a } \\
\text { sexual leisure mentality } \\
\text { ( }<<0.05 \text { ) and agreed with } \\
\text { assumptions regarding the } \\
\text { sexual desires of males } \\
(\mathrm{p}<0.01) \text {. }\end{array}$ \\
\hline $\begin{array}{l}\text { Lou } \text { et al./ } \\
2012\end{array}$ & $\begin{array}{l}\text { Cross } \\
\text { sectional }\end{array}$ & $\begin{array}{l}\text { Adolescents } \\
\text { and young } \\
\text { adults from } \\
\text { Hanoi, } \\
\text { Shanghai } \\
\text { and Taipei }\end{array}$ & $\begin{array}{l}16,554 \\
\text { unmarried } \\
\text { respondents } \\
\text { (male and } \\
\text { female) }\end{array}$ & $\begin{array}{l}\text { Mass media (the } \\
\text { internet and } \\
\text { traditional } \\
\text { media), } \\
\text { pornographic } \\
\text { video, Western/ } \\
\text { Asian movies/ } \\
\text { videos. }\end{array}$ & $\begin{array}{l}\text { Sexual } \\
\text { knowledge, } \\
\text { attitudes and } \\
\text { behaviors }\end{array}$ & $\begin{array}{l}\text { Half of respondents } \\
\text { reported learning about } \\
\text { sex from the internet in } \\
\text { three cities }(45 \%-84 \%) \text {; } \\
\text { the highest percentage } \\
\text { was in Taipei. } \\
\text { In Taipei, sex-related } \\
\text { comprehension and sex- } \\
\text { related conduct ratings } \\
\text { were the largest. }\end{array}$ \\
\hline $\begin{array}{l}\text { Stulhofer, } \\
\text { Busko and } \\
\text { Schmidt/ } \\
2012\end{array}$ & $\begin{array}{l}\text { Online } \\
\text { questionnaire }\end{array}$ & $\begin{array}{l}\text { Croatian } \\
\text { students }\end{array}$ & $\begin{array}{l}544 \\
\text { respondents } \\
\text { (male and } \\
\text { female) }\end{array}$ & $\begin{array}{l}\text { Internet-based } \\
\text { pornography }\end{array}$ & $\begin{array}{l}\text { Recretional sex } \\
\text { Relationship } \\
\text { intimacy }\end{array}$ & $\begin{array}{l}\text { The mean age of sexual } \\
\text { debut was } 17.5 \\
(\mathrm{SD}=2.11) \text {. } \\
\text { Most participants } \\
\text { mentioned being in a } \\
\text { relationship at the } \\
\text { moment }(69.3 \%) \text {. }\end{array}$ \\
\hline $\begin{array}{l}\text { Vandenbosch } \\
\text { and } \\
\text { Eggermont/ } \\
2013\end{array}$ & $\begin{array}{l}\text { A quantitative } \\
\text { survey }\end{array}$ & $\begin{array}{l}\text { Belgium } \\
\text { adolescent } \\
\text { boys }\end{array}$ & $\begin{array}{l}911 \\
\text { adolescent } \\
\text { boys }\end{array}$ & $\begin{array}{l}\text { Sexualizing } \\
\text { media }\end{array}$ & Body Surveillance & $\begin{array}{l}\text { The mean level of } \\
\text { significance attached to } \\
\text { attributes based on } \\
\text { competence was } \\
\text { significantly higher than } \\
\text { attributes based on } \\
\text { appearance p<0.001. }\end{array}$ \\
\hline $\begin{array}{l}\text { Kumar et al./ } \\
2013\end{array}$ & $\begin{array}{l}\text { Cross } \\
\text { sectional } \\
\text { study }\end{array}$ & $\begin{array}{l}\text { Indian } \\
\text { students } \\
\text { class IX- } \\
\text { XII. }\end{array}$ & $\begin{array}{l}586 \\
\text { adolescent } \\
\text { boys and } \\
\text { girls. }\end{array}$ & $\begin{array}{l}\text { Television } \\
\text { Internet }\end{array}$ & $\begin{array}{l}\text { Sexual contact } \\
\text { Academic } \\
\text { achievement }\end{array}$ & $\begin{array}{l}\text { There was a strong } \\
\text { positive correlation } \\
\text { between sexual interaction } \\
\text { and average academic } \\
\text { score and unsupervised } \\
\text { use of the internet among } \\
\text { boys. }\end{array}$ \\
\hline
\end{tabular}




\begin{tabular}{|c|c|c|c|c|c|c|}
\hline $\begin{array}{l}\text { Vandenbosch } \\
\text { and } \\
\text { Eggermont/ } \\
2014\end{array}$ & $\begin{array}{l}\text { A three-wave } \\
\text { panel study }\end{array}$ & $\begin{array}{l}\text { Flanders' } \\
\text { (the Dutch- } \\
\text { speaking } \\
\text { part of } \\
\text { Belgium) } \\
\text { adolescents }\end{array}$ & $\begin{array}{l}1041 \\
\text { students } \\
(589 \text { boys } \\
\text { and } 452 \\
\text { girls) }\end{array}$ & Television & $\begin{array}{l}\text { Self- } \\
\text { objectification } \\
\text { Gendered sexual } \\
\text { roles }\end{array}$ & $\begin{array}{l}\text { The model showed that } \\
\text { the recognition of } \\
\text { gendered sexual roles at } \\
\text { wave } 3 \text { was not predicted } \\
\text { by viewing sexualized } \\
\text { sitcoms at wave } 1(\mathrm{p}> \\
0.05) \text {. }\end{array}$ \\
\hline $\begin{array}{l}\text { Ybarra and } \\
\text { Mitchell/ } \\
2014\end{array}$ & $\begin{array}{l}\text { Cross } \\
\text { sectional } \\
\text { study (Online } \\
\text { survey) }\end{array}$ & $\begin{array}{l}\text { United } \\
\text { States's } \\
\text { adolescents }\end{array}$ & 3715 youth & Sexting & $\begin{array}{l}\text { Sexual risk } \\
\text { behavior }\end{array}$ & $\begin{array}{l}\text { Compared to } 13 \% \text { of } \\
\text { males who did not, } 51 \% \\
\text { of male teenagers who did } \\
\text { sexting had vaginal sex. }\end{array}$ \\
\hline $\begin{array}{l}\text { Livingstone } \\
\text { and Gorzig/ } \\
2014\end{array}$ & $\begin{array}{l}\text { Cross } \\
\text { sectional }\end{array}$ & $\begin{array}{l}\text { European } \\
\text { children } \\
\text { and } \\
\text { adolescent } \\
\text { aged 9-16 } \\
\text { years. }\end{array}$ & $\begin{array}{l}18,709 \text { boys } \\
\text { and girls }\end{array}$ & Sexting & $\begin{array}{l}\text { Sexual risk and } \\
\text { harm }\end{array}$ & $\begin{array}{l}\text { Older age, higher } \\
\text { psychological problems, } \\
\text { greater thrill seeking and } \\
\text { greater risky online and } \\
\text { offline activity are the key } \\
\text { predictors of the } \\
\text { likelihood of seeing or } \\
\text { receiving sexual messages } \\
\text { online. }\end{array}$ \\
\hline $\begin{array}{l}\text { Mattebo et } \\
\text { al./ } 2014\end{array}$ & $\begin{array}{l}\text { A population- } \\
\text { based } \\
\text { classroom } \\
\text { survey }\end{array}$ & $\begin{array}{l}\text { Sweden } \\
\text { high school } \\
\text { students }\end{array}$ & $\begin{array}{l}477 \text { boys } \\
\text { and } 400 \\
\text { girls }\end{array}$ & $\begin{array}{l}\text { Pornography } \\
\text { media }\end{array}$ & Sexual abuse & $\begin{array}{l}\text { A greater proportion of } \\
\text { girls }(15 \%) \text { have } \\
\text { witnessed sexual } \\
\text { harassment than boys } \\
(6 \%) \text {. }\end{array}$ \\
\hline $\begin{array}{l}\text { Ouytsel, } \\
\text { Ponnet and } \\
\text { Walrave/ } \\
2014\end{array}$ & $\begin{array}{l}\text { Cross } \\
\text { sectional } \\
\text { survey }\end{array}$ & $\begin{array}{l}\text { Belgium } \\
\text { secondary } \\
\text { school } \\
\text { students }\end{array}$ & $\begin{array}{l}131 \text { boys } \\
\text { and } 198 \\
\text { girls }\end{array}$ & $\begin{array}{l}\text { Pornography and } \\
\text { music videos }\end{array}$ & Sexting behavior & $\begin{array}{l}\text { Sexting habits were } \\
\text { closely correlated with the } \\
\text { consumption of } \\
\text { pornography; for age, } \\
\text { gender, school track and } \\
\text { internet usage while } \\
\text { regulating. }\end{array}$ \\
\hline $\begin{array}{l}\text { Doornwaard. } \\
\text { et al./ } 2014\end{array}$ & Survey & $\begin{array}{l}\text { Dutch } \\
\text { adolescents }\end{array}$ & $\begin{array}{l}104 \text { of } \\
\text { adolescents } \\
\text { Facebook } \\
\text { profiles }\end{array}$ & Facebook profiles & Sexual identity & $\begin{array}{l}\text { Sexual displayers were } \\
\text { more likely boys and } \\
\text { more sexually interested. }\end{array}$ \\
\hline $\begin{array}{l}\text { van Oosten, } \\
\text { Peter and } \\
\text { Boot/ } 2015\end{array}$ & $\begin{array}{l}\text { A two-wave } \\
\text { panel study }\end{array}$ & $\begin{array}{l}\text { Ducth } \\
\text { adolescents }\end{array}$ & $\begin{array}{l}1,636 \\
\text { participants } \\
\text { in wave } 1 \\
\text { and } 1586 \\
\text { participants } \\
\text { in wave } 2\end{array}$ & $\begin{array}{l}\text { Sosial network } \\
\text { sites }\end{array}$ & $\begin{array}{l}\text { Sexual attitudes } \\
\text { and behavior }\end{array}$ & $\begin{array}{l}\text { Six months later, } \\
\text { exposure to attractive } \\
\text { online self-presentations } \\
\text { of others expected } \\
\text { improvements in the } \\
\text { experience of teenagers } \\
\text { with oral sex and } \\
\text { intercourse, but did not } \\
\text { affect their sexual } \\
\text { attitudes. }\end{array}$ \\
\hline $\begin{array}{l}\text { Vandenbosch } \\
\text { and } \\
\text { Eggermont/ } \\
2015\end{array}$ & $\begin{array}{l}\text { A three-wave } \\
\text { panel study }\end{array}$ & $\begin{array}{l}\text { Belgium } \\
\text { students }\end{array}$ & $\begin{array}{l}1,504 \\
\text { students in } \\
\text { wave } 1 \\
1,426 \\
\text { students in } \\
\text { wave } 2 \\
1,433 \\
\text { students in } \\
\text { wave } 3\end{array}$ & Magazines & $\begin{array}{l}\text { Sexual behaviors } \\
\text { Self- } \\
\text { objectification }\end{array}$ & $\begin{array}{l}\text { The reading of } \\
\text { pornographic magazines } \\
\text { was connected to the } \\
\text { internalization of the } \\
\text { values of beauty and the } \\
\text { appreciation of } \\
\text { appearance over } \\
\text { competence (wave 1). For } \\
\text { intimate contact, no } \\
\text { significant connection } \\
\text { was noted. }\end{array}$ \\
\hline $\begin{array}{l}\text { Doorwaard. et } \\
\text { al./ } 2015\end{array}$ & $\begin{array}{l}\text { A four-wave } \\
\text { longitudinal } \\
\text { study }\end{array}$ & $\begin{array}{l}\text { Dutch } \\
\text { adolescents }\end{array}$ & $\begin{array}{l}1,132 \\
\text { adolescents } \\
(52.7 \% \\
\text { boys })\end{array}$ & $\begin{array}{l}\text { SEIM (Sexually } \\
\text { Explicit Internet } \\
\text { Material) }\end{array}$ & $\begin{array}{l}\text { Sexual attitudes } \\
\text { and behavior }\end{array}$ & $\begin{array}{l}\text { Girls showed a similar } \\
\text { trend of increases in } \\
\text { sexual conduct } \\
\text { experience, but their use } \\
\text { of SEIM was consistently } \\
\text { low and their endorsement } \\
\text { of permissive sexual } \\
\text { attitudes decreased over } \\
\text { the study span of } 18 \\
\text { months. }\end{array}$ \\
\hline $\begin{array}{l}\text { Sarabia and } \\
\text { Estevez/ } 2016\end{array}$ & $\begin{array}{l}\text { An } \\
\text { exploratory } \\
\text { and } \\
\text { descriptive } \\
\text { study }\end{array}$ & $\begin{array}{l}\text { Spain } \\
\text { adolescents }\end{array}$ & $\begin{array}{l}100 \text { of } \\
\text { adolescent } \\
\text { Facebook } \\
\text { profiles }\end{array}$ & Facebook profiles & $\begin{array}{l}\text { Sexualized } \\
\text { behaviors through } \\
\text { social networks }\end{array}$ & $\begin{array}{l}\text { For these types of } \\
\text { behaviors, the findings } \\
\text { showed gender disparities, } \\
\text { and sexualized behaviors } \\
\text { were reinforced by } \\
\text { vulnerability factors. }\end{array}$ \\
\hline
\end{tabular}




\begin{tabular}{|c|c|c|c|c|c|c|}
\hline $\begin{array}{l}\text { Donevan and } \\
\text { Mattebo/ } \\
2017\end{array}$ & $\begin{array}{l}\text { A cross } \\
\text { sectional }\end{array}$ & $\begin{array}{l}\text { Swedish } \\
\text { adolescent } \\
\text { boys }\end{array}$ & 371 boys & $\begin{array}{l}\text { Pornography } \\
\text { consumption }\end{array}$ & $\begin{array}{l}\text { Sexual behaviors } \\
\text { Sexual } \\
\text { preoccupancy }\end{array}$ & $\begin{array}{l}\text { In a broader spectrum of } \\
\text { sexual behaviors, regular } \\
\text { participants were more } \\
\text { likely to have } \\
\text { participated. }\end{array}$ \\
\hline $\begin{array}{l}\text { Romo et al./ } \\
2017\end{array}$ & $\begin{array}{l}\text { A cross } \\
\text { sectional } \\
\text { study }\end{array}$ & $\begin{array}{l}\text { Hispanic } \\
\text { adolescents }\end{array}$ & $\begin{array}{l}333 \\
\text { adolescents } \\
\text { boys and } \\
\text { girls }\end{array}$ & Social media use & $\begin{array}{l}\text { Sexual risk } \\
\text { Parental } \\
\text { monitoring }\end{array}$ & $\begin{array}{l}\text { There were equal levels of } \\
\text { oral, vaginal and anal } \\
\text { sexual activity recorded } \\
\text { by male and female } \\
\text { participants. } \\
48.4 \text { percent of } \\
\text { participants reported full } \\
\text { parental access to social } \\
\text { networking site profiles. }\end{array}$ \\
\hline $\begin{array}{l}\text { Martyniuk } \\
\text { and Stulhofer/ } \\
2018\end{array}$ & $\begin{array}{l}\text { Online survey } \\
\text { and class } \\
\text { room-based } \\
\text { survey }\end{array}$ & $\begin{array}{l}\text { Croatian } \\
\text { high school } \\
\text { students }\end{array}$ & $\begin{array}{l}\text { Online } \\
\text { survey } \\
n=372 \\
\text { Class room- } \\
\text { based } \\
\text { survey } \\
n=753\end{array}$ & Pornography use & $\begin{array}{l}\text { Sexual } \\
\text { permissiveness }\end{array}$ & $\begin{array}{l}\text { Participants reported } \\
\text { relatively low levels of } \\
\text { permissiveness, but } \\
\text { primarily teenage men } \\
\text { used extensive } \\
\text { pornography. }\end{array}$ \\
\hline $\begin{array}{l}\text { Daneback, } \\
\text { Sevcikova } \\
\text { and Jezek/ } \\
2018\end{array}$ & $\begin{array}{l}\text { A three-wave } \\
\text { longitudinal } \\
\text { study }\end{array}$ & $\begin{array}{l}\text { Czech } \\
\text { adolescents }\end{array}$ & $\begin{array}{l}1,134 \text { girls } \\
\text { from } 55 \\
\text { schools }\end{array}$ & $\begin{array}{l}\text { Online sexual } \\
\text { materials (images } \\
\text { and videos) }\end{array}$ & $\begin{array}{l}\text { Desensitization to } \\
\text { sexual content }\end{array}$ & $\begin{array}{l}\text { In terms of being less } \\
\text { disturbed by the sexual } \\
\text { stuff, respondents were } \\
\text { desensitized. }\end{array}$ \\
\hline
\end{tabular}

According to research, after watching pornography, male adolescents felt the need to try out what they had seen in real life, with the mean sexual age debut of the respondents at 17.5 years [25], [26]. Moreover, the study of Vandenbosch and Eggermont found out that the internalization of non-appearing ideals can be predicted by viewing sexualizing television [18]. A study of Croation adolescents also discovered that in two cities, Zagreb and Rijeka, 22.9\% and 27\% of male adolescents' respectively, use pornography on a daily basis. Also, in Zagreb, there was a significant increase between sexual permissiveness and the use of pornography, but in Rijeka, a significant difference was only found in the initial and final scores of its use [27].

\subsection{Sexual behaviors}

Lou studied the media's contribution to the sexual knowledge, attitude and behavior of adolescents in three Asian cities and found that 45-84\% of them learned about sexuality from the internet [10]. Furthermore, the study of pornography on sexual behavior in adolescents was also conducted by Mattebo and Tyden, where all male $(96 \%)$ and female $(54 \%)$ respondents used in the research had seen various media content containing pornography, and $15 \%$ of the females had experienced sexual abuse as compared to the male respondents [28]. In addition to viewing media content containing pornography, teens also use social networks to send and view Facebook profiles that contain various provocative images and videos. The study of Doornwaard also discovered that male adolescents were more likely to become sexual adventurers than their female counterparts [28]. Moreover, Sarabia also believed that social networking sites used by them to send and receive selfies in order to communicate with each other, can indeed promote sexualized behaviors, which is in line with the study results of van Oosten [29], [30]. Sexting behaviors are also profound among adolescents, since they are used to using digital technology through their smart phones [31], [32].

\subsection{Sexual initiation}

Study about pubertal status and sexual initiation in adolescents found out that at the advanced pubertal stage, these individuals will be four times more likely to initiate sexual activity than when they are in the early stages of puberty. In addition, teens who often view sexually explicit websites are five times more likely to initiate sexual activity than non-users [33], [34]. However, Matkovic concluded that there is a lack of significant relationship between sexually explicit material use and sexual debut on Croatian adolescents [35].

\subsection{Sexual risks}

Study about sexting believed that sexting had an impact that did not always provide a pleasant experience for adolescents. The risk of sexting increases significantly with age by at least $50 \%$ every year. The high desire to carry out sexting is related to the high desire to accept sexting messages twice per scale point. Online and offline activities are also associated with the $50 \%$ increase in their desire to receive sexual messages per single texting activity [36]. Indeed, Ybarra found that 51\% of male participants who sent or 
showed sexual images had sexual intercourse as compared to $13 \%$ of men who had never done sexting [37]. Yet, sexting behaviors stimulate sexual risks such as sexual coercion and unprotected vaginal and/ or oral sex [38], [39].

\subsection{Parental monitoring}

A study from Romo showed that $48.4 \%$ of female participants reported that their parents could access Facebook profiles because they became their friends or followers on Facebook. Another 54.6\% of the participants also claimed that their parents always discussed the importance of the privacy settings of their Facebook profile. This result is inversely proportional to the results of the research carried out on the male participants. Romo's study also found no relationship between parental supervision of sexual media use by adolescents [40]. These study's result incongruent with Landry's finding related to parents' supervision where parent did a great portion as protective factor in decreasing adolescent sexual risks [41], [42].

\subsection{Academic achievement}

It is undeniable that when adolescents engaged in early sexual activity, the achievement of academic values will be affected [43], [44]. Kumar reported that there were no significant differences in test scores between female adolescents who had contact with sexual activities and those who had never engaged in any form of sexual relations. This result is inversely proportional when seen in the male participants. Consequently, it was also observed that the male counterparts who have had sexual activity, had test scores ranging from 51-70\%, while scores above $90 \%$ were obtained in male adolescents who had never had any sexual interactions with the opposite sex. In terms of the relationship between academic achievement and preoccupations related to sexual activities, there was no significant relationship observed in the study [45].

\subsection{Gender}

Another study by Vandenbosch showed that, if there is an increase in the rate at which male adolescents view television media, there would also be a concurrent increase in their tendency to develop recreational sexual attitudes. This hypothesis ultimately agrees with the stereotypical views associated with male sexual needs. However, these results found a relationship that was not too significant between their desire to see television and the various stereotypic views surrounding their sexual needs, as well as the absence of a relationship between maternal attachment and male sexuality stereotypes [46]

\subsection{Limitation}

In relation to the projects' limitations, this review include research designs, number of respondents, lost or inconsequential data, types of pornographic media and possible cultural factors that influenced its results from the papers reviewed. Some studies used a cross sectional design which made it very difficult to ascertain causality. Others used two-wave, three-wave and four-wave design panels with a six months time interval, which allowed for incompatibility in data analysis [18], [30], [33], [47]-[49]. In addition, some projects used both online and offline surveys which resulted in inconsistent data due to the possibility of dishonesty of respondents when answering questionnaires [46], [50]. In terms of the number of participants used in the longitudinal projects, some of them did not explain the reasons for participant drop-outs in each existing wave. The inequality of the number of participants in the project using longitudinal approaches and the unclear follow-up of participants who dropped out allowed inconsistent data to occur, which created a statistical bias.

Furthermore, several studies being reviewed also had various means of accessing pornographic media. Seven of them used the term pornography to refer to images and videos that contained sexual content. Four, used television media as a platform that provides pornographic content. Three, made use of various websites as a method of providing pornography online, while sexting and magazines were used by other projects simultaneously. In addition, four researches used the facebook profiles of the participants as the main source of pornography, during the entire survey. Other sections of the user's account were not accessible because of the limitations of the privacy settings set by the participants. Moreover, differences in definitions regarding sexually explicit materials makes it very difficult to understand the concept of pornographic media.

Regarding cultural factors, some projects were carried out in locations that held liberal or secular principles about pornography, where exposure to these kind of content is fairly free. This indirectly affected the response of teen participants, which consequently limited the results of the study to a particular location. Moreover, research conducted in locations that still adhere to gender stereotypes also produced data that affected statistical significance.

Using cross-sectional designs, this project was unable to determine the causality between the different research variables. Therefore, further studies that are related to media and social networking sites 
containing pornographic content are expected to use longitudinal designs, a controlled time lag, and a designated number of male and female respondents. This will allow such study to be able to avoid any and all statistical bias. Moreover, a qualitative research will further explore youth experiences regarding the use of pornography and sexual behavior [36], [51].

In terms of the definition of sexualized media, research must clearly define or state the different media variables used, such that the data obtained can be valid and used as a baseline in the near future. In case the research location still holds traditional views related to pornography, an accurate sexual education must be carried out so as to avoid any negative impact of sexualized media on adolescent behaviors [10]. Subsequently, research must also consider the validity of data statistically, especially if it relates to a location that already has gender stereotypes associated with their sexual needs.

\section{CONCLUSION}

Conclusively, given the prevailing increase in the number of adolescents who use smart phones, systematic reviews related to the role of pornographic media and social networking sites on the sexual activity and behavior of adolescents need to be conducted. This will consequently provide relevant information on why they feel the need to access sexual content via various media. These sexual contents can either have a positive or negative effect on these adolescents by either improving the knowledge they have on the sexuality of the opposite sex or leading them to risky or bad sexual behaviors respectively. Hence, the limitations of previous projects should be used as a reference to examine further studies such that the implications of future researches can be generalized.

\section{ACKNOWLEDGEMENTS}

Authors would like to express our gratitude to the Dean of the Faculty of Public Health and Chair of the Public Health Doctoral Program at Universitas Airlangga-Surabaya Indonesia and the Dean of the Faculty of Medicine, University of Brawijaya-Malang Indonesia for the implementation of this study

\section{REFERENCES}

[1] Conway K.P et al., "Association of Lifetime Mental Disorders and Subsequent Alcohol and Illicit Drug Use: Results From the National Comorbidity Survey-Adolescent Supplement," Journal of the American Academy of Child and Adolescent Psychiatry, vol. 55, no. 4, pp. 280-288, 2016.

[2] Rhodes J.D et al., "Cigarette smoking and ADHD: An examination of prognostically relevant smoking behaviors among adolescents and young adults," Psychology of Addictive Behaviors, vol. 30, no. 5, pp. 588-600, 2016.

[3] Wilkinson A.L et al., "Directions of the relationship between substance use and depressive symptoms from adolescence to young adulthood," Addictive Behaviors, vol. 60, pp. 64-70, 2016.

[4] Wahed T et al., "A narrative review of the literature on the reproductive health of female sex workers having age below twenty years," Bangladesh Journal of Medical Science, vol. 19, no. 1, pp. 17-31, 2019.

[5] Branley D. B. and Covey J., "Is exposure to online content depicting risky behavior related to viewers' own risky behavior offline?," Computers in Human Behavior, vol. 75, pp. 283-287, 2017.

[6] Gámez-Guadix M et al., "Risky online behaviors among adolescents: Longitudinal relations among problematic Internet use, cyberbullying perpetration, and meeting strangers online," Journal Behaviors Addictive, vol. 5, no. 1, pp. 100-107, 2016.

[7] Eleuteri S., Saladino V., and Verrastro V., "Identity, relationships, sexuality, and risky behaviors of adolescents in the context of social media," Sexual and Relationship Therapy, vol. 32, no. 3-4, pp. 354-365, 2017.

[8] Lim M. S. C. et al., "Young Australians' use of pornography and associations with sexual risk behaviours," Australian New Zeland Journal Public Health, vol. 41, no. 4, pp. 438-443, 2017.

[9] Grubbs J.B. et al., "Internet pornography use and sexual motivation: a systematic review and integration," Annals of the International Communication Association, vol. 43, no. 2, pp. 117-155, 2019.

[10] Lou C. et al., "Media's Contribution to Sexual Knowledge, Attitudes, and Behaviors for Adolescents and Young Adults in Three Asian Cities," Journal Adolescent Health, vol. 50, no. 3, pp. S26-S36, 2012.

[11] Attwood F., Smith C., and Barker M., "I"m just curious and still exploring myself': Young people and pornography," New Media Society, vol. 20, no. 10, pp. 3738-3759, 2018.

[12] Harper, C., and Hodgins, D.C., "Examining Correlates of Problematic Internet Pornography Use Among University Students," Journal Behaviors Addictive, vol. 5, no. 2, pp. 179-191, 2016.

[13] Braun-Courville D.K., Rojas M., "Exposure to Sexually Explicit Web Sites and Adolescent Sexual Attitudes and Behaviors," Journal Adolescent Health, vol. 45, no. 2, pp. 156-162, 2009.

[14] Scarcelli C. M., ““'It is disgusting, but...": adolescent girls' relationship to internet pornography as gender performance," Porn Studies, vol. 2, no. 2-3, pp. 237-249, 2015.

[15] Mattebo M et al., "Pornography and Sexual Experiences Among High School Students in Sweden," Journal of Developmental and Behavioral Pediatrics, vol. 35, no. 3, pp. 179-188, 2014. 
[16] Donevan M. and Mattebo M., "The relationship between frequent pornography consumption, behaviours, and sexual preoccupancy among male adolescents in Sweden," Sexual and Reproductive Healthcare, vol. 12, pp. 82-87, 2017.

[17] Chen L et al., "The relationship between sexual sensation seeking and problematic Internet pornography use: A moderated mediation model examining roles of online sexual activities and the third-person effect," Journal of Behavioral Addictions, vol. 7, no. 3, pp. 565-573, 2018.

[18] Vandenbosch L., Eggermont S., "The role of television in adolescents' sexual attitudes: Exploring the explanatory value of the three-step self-objectification process," Poetics, vol. 45, pp. 19-35, 2014.

[19] Vangeel L., Eggermont S. and Vandenbosch L., "Does adolescent media use predict sexual stereotypes in adolescence and emerging adulthood? Associations with music television and online pornography exposure," Archives of Sexual Behavior, vol. 49, no. 4, pp. 1147-1161, 2020.

[20] Valkenburg P.M and Peter J., "Online communication among adolescents: an integrated model of its attraction, opportunities, and risks," Journal Adolescent Health, vol. 48, no. 2, pp. 121-127, 2011.

[21] Rice E et al., "Cell phone internet access, online sexual solicitation, partner seeking, and sexual risk behavior among adolescents," Archives of Sexual Behavior, vol. 44, no. 3, pp. 755-763, 2014.

[22] Bersamin M. et al., "Parenting practices and adolescent sexual behavior: A longitudinal study," Journal of Marriage and Family, vol. 70, no. 1, pp. 97-112, 2008.

[23] Rasmussen E. E., Ortiz R. R and White S. R., "Emerging adults' responses to active mediation of pornography during adolescence," Journal Children Media, vol. 9, no. 2, pp. 160-176, 2015.

[24] PRISMA. Available at: www.prisma-statement.org. Accessed November 7, 2020.

[25] Svedin C.G et al., "Frequent users of pornography. A population based epidemiological study of Swedish male adolescents," Journal Adolescent, vol. 34:, no. 4, pp. 779-788, 2011.

[26] Stulhofer A et al., "Adolescent exposure to pornography and relationship intimacy in young adulthood," Psychology and Sexuality, vol. 3, no. 2, pp. 95-107, 2012.

[27] Martyniuk U and Stulhofer A., "A longitudinal exploration of the relationship between pornography use and sexual permissiveness in female and male adolescents," Journal Adolescent, vol. 69: 80-87, 2018.

[28] Doornwaard S.M et al., "Young adolescents' sexual and romantic reference displays on facebook," Journal Adolescent Health, vol. 55, no. 4, pp. 535-541, 2014.

[29] Sarabia, I and Estevez, A., "Sexualized behaviors on Facebook," Computers in Human Behavior, vol. 61, pp. 219226, 2016.

[30] Van Oosten J.M.F., Peter J., and Boot I., "Exploring associations between exposure to sexy online selfpresentations and adolescents' sexual attitudes and behavior," Journal Youth Adolescence, vol. 44, no. 5, pp. 1078$1091,2015$.

[31] Van Ouytsel J., Ponnet K., Walrave M., "The associations between adolescents' consumption of pornography and music videos and their sexting behavior," Cyberpsychology, Behavior, and Social Networking, vol. 17, no. 12, pp. $1-7,2014$.

[32] Van Ouytsel J et al., "Sexting: adolescents' perceptions of the applications used for, motives for, and consequences of sexting," Journal Youth Studies, vol. 20, no. 4, pp. 446-470, 2017.

[33] Vandenbosch L and Eggermont S., "Sexually Explicit Websites and Sexual Initiation: Reciprocal Relationships and the Moderating Role of Pubertal Status," Journal Research Adolescence, vol. 23, no. 4, pp. 621-634, 2012.

[34] Atwood K.A et al., "Correlates of Precoital Behaviors, Intentions, and Sexual Initiation Among Thai Adolescents," Journal Early Adolescence, vol. 32, no. 3, pp. 364-386, 2012.

[35] Matković, T., Cohen N., and Štulhofer A., "The Use of Sexually Explicit Material and Its Relationship to Adolescent Sexual Activity," Journal of Adolescent Health, vol. 62, no. 5, pp. 563-569, 2018.

[36] Livingstone S and Gorzig, A., "When adolescents receive sexual messages on the internet: Explaining experiences of risk and harm," Computers in Human Behavior, vol. 33, pp. 8-15, 2014.

[37] Ybarra M.L and Mitchell K.J., "Sexting" and its relation to sexual activity and sexual risk behavior in a national survey of adolescents," Journal Adolescent Health, vol. 55, no. 6, pp. 757-764, 2014.

[38] Choi H., Van Ouytsel J., and Temple J.R., "Association between sexting and sexual coercion among female adolescents," Journal Adolescence, vol. 53, pp. 164-168, 2016.

[39] Davis M. J et al., "I want your sext: Sexting and sexual risk in emerging adult minority men," AIDS Education Prevention, vol. 28, no. 2, pp. 138-152, 2016.

[40] Romo D.L et al., "Social media use and its association with sexual risk and parental monitoring among a primarily hispanic adolescent population," Journal Pediatric Adolescent Gynecology, vol. 30, no. 4, pp. 466-473, 2017.

[41] Landry M et al., "Social media and sexual behavior among adolescents: is there a link?," JMIR Public Health Surveillance, vol. 3, no. 2, p. e28, 2017.

[42] Tomić I., Burić J., Štulhofer A., "Associations between croatian adolescents' use of sexually explicit material and sexual behavior: does parental monitoring play a role?," Archives of Sexual Behavior, vol. 47, no. 6, pp. 1881-1893, 2018.

[43] Collins R.L et al., "Watching sex on television predicts adolescent initiation of sexual behavior," Pediatrics, vol. 114, no. 3, pp. e280-e289, 2004.

[44] Beyens I., Vandenbosch L., Eggermont S., "Early adolescent boys' exposure to internet pornography," Journal Early Adolescence, vol. 35, no. 8, pp. 1045-1068, 2014.

[45] Shashi Kumar, R et al., "Interaction of media, sexual activity and academic achievement in adolescents," Medical Journal Armed Forces India, vol. 69, no. 2, pp. 138-143, 2013. 
[46] Vandenbosch L and Eggermont S., "Maternal attachment and television viewing in adolescents' sexual socialization: differential associations across gender," Sex Roles, vol. 66, pp. 38-52, 2012.

[47] Vandenbosch L., Eggermont S., "The role of mass media in adolescents' sexual behaviors: exploring the explanatory value of the three-step self-objectification process," Archives of Sexual Behavior, vol. 44, no. 3, pp. 729-742, 2015.

[48] Doornwaard S.M et al., "Adolescents' use of sexually explicit internet material and their sexual attitudes and behavior: parallel development and directional effects," Developmental Psychology, vol. 51, no. 10, pp. 1476-1488, 2015.

[49] Daneback K., Sevcíková A and Jezek S., "Exposure to online sexual materials in adolescence and desensitization to sexual content," Sexologies, vol. 27, no. 3, pp. e71-e76, 2018.

[50] Vandenbosch, L and Eggermont, S., "Sexualization of adolescent boys: Media exposure and boys' internalization of appearance ideals, self-objectification, and body surveillance," Men and Masculinities, vol. 16, no. 3, pp. 283306, 2013.

[51] Rothman E.F et al., "Without porn ... i wouldn't know half the things i know now": A qualitative study of pornography use among a sample of urban, low-income, black and hispanic youth," Journal Sex Research, vol. 52, no. 7, pp. 736-746, 2015. 